\title{
Analysis of Community Self-Assistance Level in Water Resources Conservation in the Upper Areas of Renggung Watershed Lombok Island
}

\author{
Lalu Sukardi $^{1}$, Andi Chairil Ichsan ${ }^{1 *}$, Indra Gumay Febryano ${ }^{2}$, Muhamad Husni Idris ${ }^{1}$, Bambang Dipokusumo ${ }^{1}$ \\ ${ }^{1}$ Faculty of Agriculture, University of Mataram, Mataram 83115, Indonesia \\ ${ }^{2}$ Faculty of Agriculture, Universitas Lampung, Bandar Lampung 35145, Indonesia
}

Corresponding Author Email: 1sukardi@unram.ac.id

https://doi.org/10.18280/ijdne.160405

Received: 20 June 2021

Accepted: 27 July 2021

\section{Keywords:}

self-assistance, conservation, water, watershed

\begin{abstract}
This study aims to analyze the initiative and level of community self-assistance in water resources conservation, analyze the influence of family socio-economic characteristics on the level of self-assistance in water resources conservation, and formulate a selfassistance conservation model in the upstream area of the Renggung watershed. This research was carried out in the upstream area of the Renggung watershed. Data were collected observation, in-depth interviews, document review. Data were analyzed based on a Likert scale and multiple regression. The results of the study are as follows: (1) Initiatives and the level of community self-assistance in the conservation of water resources in the upstream area of the Renggung watershed are classified in the "Low" category; (2) The socio-economic characteristics of the family that have a significant effect on the level of self-assistance are age and income. Age has a positive effect, while income has a negative effect; and (3) Self-assistance conservation models that can be developed are: Development of Village-owned Fruit and Ornamental Plant Tourism Parks; Productive Economic Business Empowerment; and Development of Conservation Crop Compensation.
\end{abstract}

\section{INTRODUCTION}

Condition of natural resources especially water is strongly affected by human activities [1-4]. Efforts to maintain the sustainability of water availability can be done through water resources conservation activities [5-10]. According to Kodotie, and Syarief [11], water resources conservation activities consist of three main activities, namely: (1) protection and preservation of water resources, (2) water preservation, and (3) water quality management and water pollution control. Furthermore, Sudarmadji et al. [5, 12] emphasized that the support and role of participation from various parties, including the government, the business world, higher education institutions and community groups are very much needed in preserving water resources through conservation activities. Various conservation efforts have been made in the form of mass community service, field schools, technical assistance, pilot projects. More holistic concept is also developed namely the formation of a conservation village model (Model Desa Konservasi/MDK). The establishment of MDK was considered as the right effort, because it could unite various interests by prioritizing conservation as an important part of all activities in one area [4, 13-15].

One of the largest watersheds in Central Lombok Regency, West Nusa Tenggara (Nusa Tenggara Barat/NTB) is the Renggung Watershed. So far, the Renggung watershed is a supplier of irrigation water which irrigates most of the agricultural land in Central Lombok [16]. The Renggung Watershed also functions as a supplier of clean water needs for domestics, the livestock, fisheries and domestic industries in Central Lombok. Considering the role of the Renggung watershed in meeting the need for water, it is necessary to make an effort to maintain the availability of water in a sustainable manner both in terms of quantity and quality of water through activities to protect the area of springs. Since 2012 the Transform Institute in collaboration with Fauna Flora International (FFI-IP Lombok), Lombok Tengah Regency Government, PT Export Leaf Indonesia (ELI) and Research Center for Waters Resources and Agroclimate (RCWRA) University of Mataram have launched a spring protection movement through agroforestry development programs and Biodiversity Environment Services (BES) in the Renggung Watershed. Maria et al. [17] emphasized that the application of agroforestry is able to restore the function of soil and water conservation as a buffer system, so that it can overcome the problem of decreasing land quality and improving the community's economy.

Conservation of water resources in the upper watershed of Renggung is not only the task of the government, but also the responsibility of all components of society. The success of sustainable forest management so far is not determined by the large amount of funds disbursed for these activities, but is strongly influenced by community involvement and participation. However, according to Sukardi et al. [4, 16, 18, 19], community participation in spring conservation is mostly done in groups through spring user groups. Various environmental policies that have been released and implemented by the NTB provincial government and district governments in order to conserve water resources; including in the upstream area of the Renggung watershed. The implementation of that policies involves the community (participatory approach). The question now is the how extent 
of community initiative and self-assistance in water resources conservation activities in the upstream area of the Renggung watershed. The objectives of this study are: (1) to analyze the initiative and level of community self-assistance in water resources conservation; (2) to analyze the influence of the socio-economic characteristics of the family on the level of self-assistance in water resources conservation; and (3) to formulate self-assistance conservation models in the upstream area of the Renggung watershed.

\section{METHOD}

This research uses a descriptive method. Data and information from activities related to water resource conservation in study area were collected. A systematic, factual and accurate description of the facts, properties and relationships between the phenomena under study is made $[20,21]$. This research was conducted in the upstream area of the Renggung watershed, which is administratively located in the Kopang District and North Batukliang District, Central Lombok Regency (Figure 1). Data and information were collected using observation document review and in-depth interviews. The number of samples was determined by quota as many as 30 households.

Measurement of community self-assistance in water resources conservation was carried out by scoring formulated based on a Likert Scale [22] both for physical, non-physical activities, and financial aspects. The level of community selfassistance is assessed based on the scores of the various components as presented in Table 1. In this case, the level of community self-assistance is divided into three categories, namely low, medium, and high. In addition, influence of socio-economic characteristics of household on the level selfassistance in conserving water resources in the upstream watershed area Renggung was analyzed using multiple regression analysis.

Table 1. Components of community self-assistance assessment in water resources conservation in the Upper Renggung Watershed

\begin{tabular}{|c|c|c|c|c|c|c|c|}
\hline \multirow[t]{2}{*}{ No } & \multirow{2}{*}{\multicolumn{2}{|c|}{ Community Self-Assistance Activities }} & \multicolumn{5}{|c|}{ Score of Self-Assistance } \\
\hline & & & 1 & 2 & 3 & 4 & 5 \\
\hline \multirow[t]{4}{*}{1} & & itutional development and regulation of Conservation Areas & & & & & \\
\hline & a. & Initiative for the formation of conservation groups & $\ldots$ & $\cdots$ & $\ldots$ & $\ldots$ & $\ldots$ \\
\hline & & Initiatives for making local customary rules on conservation & $\ldots$ & $\ldots$ & $\ldots$ & $\ldots$ & .... \\
\hline & & Initiative for making village regulations on conservation & $\ldots$ & $\ldots$ & $\ldots$ & $\ldots$ & $\ldots$ \\
\hline \multirow[t]{7}{*}{2} & & Setting up conservation zone and planning activities & & & & & \\
\hline & a. & Determination of conservation area zoning & $\ldots$ & $\ldots$ & $\ldots$ & $\ldots$ & $\ldots$ \\
\hline & b. & Initiative for planning conservation activities kegiatan & $\ldots$ & $\ldots$ & $\ldots$ & $\ldots$ & $\ldots$ \\
\hline & & 1) Determination of the type and form of activity & & & & & \\
\hline & & 2) Determining the location of the activity & & & & & \\
\hline & & 3) Determination of plant types & & & & & \\
\hline & & & $\ldots$ & $\ldots$ & $\ldots$ & $\ldots$ & .... \\
\hline \multirow[t]{4}{*}{3} & & Increasing human resource capacity & & & & & \\
\hline & a. & Initiatives to learn about conservation & $\ldots$ & $\ldots$ & $\ldots$ & $\ldots$ & $\ldots$ \\
\hline & b. & Participate in conservation training/courses & $\ldots$ & $\ldots$ & $\ldots$ & $\ldots$ & .... \\
\hline & c. & Collaborating with other parties & $\ldots$ & $\ldots$ & $\ldots$ & $\ldots$ & .... \\
\hline \multirow[t]{6}{*}{4} & & Procurement of physical and supporting facilities & & & & & \\
\hline & a. & Conservation land preparation & $\ldots$ & $\ldots$ & $\ldots$ & $\ldots$ & $\ldots$ \\
\hline & b. & Setting up the nursery & $\ldots$ & $\ldots$ & $\ldots$ & $\ldots$ & .... \\
\hline & c. & Procurement of seeds & & & & & \\
\hline & d. & Procurement of fertilizers and pesticides & & & & & \\
\hline & e. & Procurement of other supporting facilities & & & & & \\
\hline \multirow[t]{15}{*}{5} & & Maintenance of conservation areas & & & & & \\
\hline & a. & Initiatives to protect vegetation in the spring area & $\ldots$ & $\ldots$ & $\ldots$ & $\ldots$ & $\ldots$ \\
\hline & b. & Initiatives to maintain the cleanliness of the spring area & $\ldots$ & $\ldots$ & $\ldots$ & $\ldots$ & .... \\
\hline & c. & Initiatives to prevent pollution in springs and canals & $\ldots$ & $\ldots$ & $\ldots$ & $\ldots$ & .... \\
\hline & d. & Initiatives to protect rainwater catchment areas & $\ldots$ & $\ldots$ & $\ldots$ & $\ldots$ & .... \\
\hline & e. & Initiative to plant trees around springs & $\ldots$ & $\ldots$ & $\ldots$ & $\ldots$ & .... \\
\hline & f. & Initiative to plant trees in forest areas & $\ldots$ & $\ldots$ & & $\ldots$ & .... \\
\hline & g. & Initiative to plant trees in own garden & $\ldots$ & $\ldots$ & $\ldots$ & $\ldots$ & $\ldots$ \\
\hline & h. & Initiative to plant trees on riverbanks & $\ldots$ & $\ldots$ & $\ldots$ & $\ldots$ & $\ldots$ \\
\hline & i. & Initiative to plant trees on the side of the road & $\ldots$ & $\ldots$ & $\ldots$ & $\ldots$ & .... \\
\hline & j. & Initiative to plant trees in public places & $\ldots$ & $\ldots$ & $\ldots$ & $\ldots$ & $\ldots$ \\
\hline & $\mathrm{k}$. & Initiative to make drainage/sanitation channels & $\ldots$ & $\ldots$ & $\ldots$ & $\ldots$ & .... \\
\hline & 1. & Initiative to build infiltration wells and biopori & $\ldots$ & $\ldots$ & $\ldots$ & $\ldots$ & .... \\
\hline & m. & Initiative to build flood-retaining buildings/floods & & & & & \\
\hline & n. & Initiative to build rainwater reservoirs & $\ldots$ & $\ldots$ & $\ldots$ & $\ldots$ & .... \\
\hline \multirow[t]{5}{*}{6} & & Funding & & & & & \\
\hline & a. & Funding for programs / activities & $\ldots$ & $\ldots$ & $\ldots$ & $\ldots$ & $\ldots$ \\
\hline & b. & Preparing funding for facilitating Program & $\ldots$ & $\ldots$ & $\ldots$ & $\ldots$ & .... \\
\hline & c. & Funding for training / meetings & $\ldots$ & $\ldots$ & $\ldots$ & $\ldots$ & $\ldots$ \\
\hline & d. & Purchase of conservation materials / equipment & $\ldots$ & $\ldots$ & $\ldots$ & $\ldots$ & $\ldots$ \\
\hline
\end{tabular}




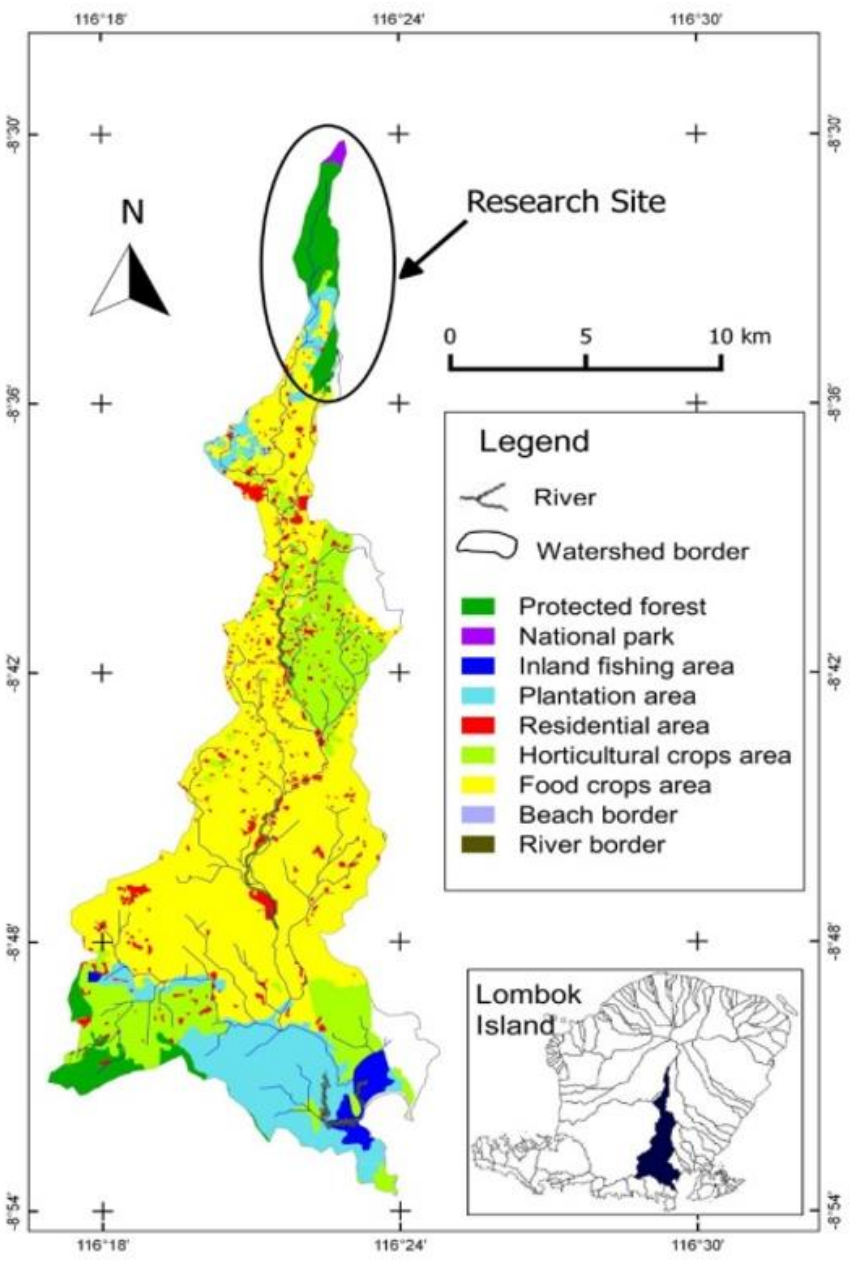

Figure 1. Research locations in the Upper Renggung Watershed

\section{RESULTS AND DISCUSSION}

3.1 Initiatives and levels of community self-assistance in water resources conservation in the Upper Renggung Watershed, Central Lombok

The results showed that more than $70 \%$ of the community knew about water resources conservation programs or activities carried out so far, both the types and forms of activities as well as the year of implementation. The activity that has been mostly carried out so far is tree planting, especially in Community Forestry (Hutan Kemasyarakatan $/ \mathrm{HKm}$ ) areas. In this case, as many as $46.67 \%$ of the community admitted to being involved, either because of their own will or invited by friends / neighbors or local village officials. There are two main reasons for their involvement, namely: (1) awareness of the importance of water conservation in the upstream area of the Renggung watershed (environmental conservation) as much as $92.86 \%$, and (2) economic motives to earn wages/income as much as $7.14 \%$.

The study results show that community involvement and participation in various water resources conservation activities in the upstream area of the Renggung watershed is passive, ie waiting for orders or orders; not be the initiator who carries out activities independently. Furthermore, to determine the extent of community self-assistance in water resources conservation activities in the upstream area of the
Renggung Watershed, an assessment using scoring was carried out based on the six components, namely: (1) Institutional development and regulation of Conservation Areas, (2) Setting up conservation zone and planning activities, (3) Increasing human resource capacity, (4) Procurement of physical and supporting facilities, (5) Maintenance of conservation areas, and (6) Funding. Each component consists of several assessment parameters as presented in Table 1.

In this case, the level of conservation self-assistance is classified into three categories, namely low, medium, and high. The results of the analysis are presented in Table 2. It can be seen that the level of community self-assistance in water resources conservation is in the category low, although in each component there are some that are in the medium category.

Table 2. Distribution of respondents by category of selfassistance communities in conserving water resources in the Upstream Renggung watershed

\begin{tabular}{|c|c|c|c|c|c|}
\hline \multirow[t]{2}{*}{ No } & \multirow{2}{*}{$\begin{array}{l}\text { Component of } \\
\text { conservation }\end{array}$} & \multicolumn{4}{|c|}{$\begin{array}{c}\text { Distribution of Respondents by } \\
\text { Category }\end{array}$} \\
\hline & & Low & Medium & High & Total \\
\hline 1 & $\begin{array}{c}\text { Institutional } \\
\text { development and } \\
\text { regulation of } \\
\text { Conservation Areas }\end{array}$ & 26 & 4 & 0 & 30 \\
\hline 2 & $\begin{array}{l}\text { Setting up } \\
\text { conservation zone } \\
\text { and planning } \\
\text { activities }\end{array}$ & 28 & 2 & 0 & 30 \\
\hline 3 & $\begin{array}{l}\text { Increasing human } \\
\text { resource capacity }\end{array}$ & 27 & 3 & 0 & 30 \\
\hline 4 & $\begin{array}{c}\text { Procurement of } \\
\text { physical and } \\
\text { supporting facilities }\end{array}$ & 29 & 1 & 0 & 30 \\
\hline 5 & $\begin{array}{l}\text { Maintenance of } \\
\text { conservation areas }\end{array}$ & 29 & 1 & 0 & 30 \\
\hline \multirow[t]{2}{*}{6} & Funding & 29 & 1 & 0 & 30 \\
\hline & Overall & 29 & 1 & 0 & 30 \\
\hline
\end{tabular}

Results of the analysis show that community initiatives for self-assistance in water resources conservation activities in the upstream area of the Renggung Watershed are in the "low" category with an average value of below $20 \%$. The main factors causing the low level of conservation initiatives are:

1. The community lacks confidence in taking the initiative and or inviting other people to take conservation actions in public areas.

2. Some people still expect economic incentives from the activities they carry out. Therefore, the initiation to develop conservation, for example by planting trees in public places or in conservation areas, is very low. They feel they do not have rights to the plants being developed.

3. Some communities acknowledge that there are those who are more responsible for conservation activities so that the community does not need to be independent. It is sufficient to participate in all conservation programs and activities, whether carried out by the government or carried out by other parties.

\subsection{The effect of family socio-economic characteristics on the level of self-assistance in water resources conservation}

To determine the factors that affect the level of self- 
assistance in water resources conservation, multiple regression analysis was carried out. In this case, the dependent variable or response variable is the community self-assistance score, while the explanatory variable or independent variable is the distance between the house and the forest area, age, area of land managed ( $\mathrm{HKm}$ and Non $\mathrm{HKm}$ ), and household income. The results are presented in Table 3.

Table 3. Analysis of the influence of family socio-economic characteristics on the level of self-assistance in water resources conservation in the upstream area the Renggung Watershed

\begin{tabular}{ccccccc}
\hline & Coefficients & Standard Error & t Stat & P-value & Lower 95\% & Upper 95\% \\
\hline Intercept & 140.2654 & 19.31271 & 7.262855 & $1.31 \mathrm{E}-07$ & 100.4902 & 180.0407 \\
X Variable 1 & 2.324744 & 4.568345 & 0.508881 & 0.615298 & -7.08394 & 11.73343 \\
X Variable 2 & -0.72487 & 0.341999 & -2.111951 & 0.044153 & -1.42923 & -0.02051 \\
X Variable 3 & -2.01259 & 10.70285 & -0.18804 & 0.852362 & $-24,0555$ & 20,03035 \\
X Variable 4 & $8,95 \mathrm{E}-07$ & $3,8 \mathrm{E}-07$ & 2,356246 & 0,026606 & $1,13 \mathrm{E}-07$ & $1,68 \mathrm{E}-06$ \\
\hline \multicolumn{6}{c}{ Notes 1 = distance between the house and the forest area, 2 = age, 3 = land area 4 = household income }
\end{tabular}

It can be seen from Table 3 that there are two factors/variables that significantly influence community selfassistance in water resources conservation in the upstream watershed area, that are age and household income. Age has a negative effect on the level of self-assistance in conservation. This means that the older a person is, the lower the level of self-assistance in water resources conservation activities and vice versa. This indicates that the younger age group is increasingly aware of and concerned about environmental sustainability, especially in water resources protection areas. On the other hand, income has a significant positive effect on the level of self-assistance in water resources conservation. The greater the household income, the higher the level of self-sufficiency in carrying out water resources conservation activities. This is in line with the study conducted by Rahadiani et al. [23] which show that community participation around Lake Beratan in water resources conservation is influenced by the age of the respondent and their income.

\subsection{Water resources self-assistance conservation model in the upper watershed, Renggung Central Lombok}

Public awareness about environmental problems has emerged, but the level of awareness is not sufficient to influence their behavior or to be a strong motivation to do actions in self-assistance to improve the environment. The non-governmental movement in handling environmental problems both in urban and rural areas has yet to be further developed. Several alternatives to increasing community selfassistance in the water resources conservation movement are:

\section{A. Providing economic and non-economic incentives}

One of the efforts that can be made to increase community self-assistance in water resource conservation is the provision of incentives, both in the form of economic and noneconomic incentives. Economic incentives can be in the form of compensation to communities who carry out conservation, for example, every tree planted in a conservation area has a reward according to the agreement. Meanwhile, noneconomic incentives can take the form of tax breaks, ease of administration services, awards, gifts, or other forms. According to [24-26] these incentives can be given individually and or in a group of people in an area.

\section{B. Granting yield rights to the community (conservation} actors)

Giving rights to the yield obtained from conservation activities will be able to encourage community initiatives to carry out conservation. For example, if there are people who plant durian or other commodities in conservation areas or in public places; then he is given the right to take the product of the plant. This is in line with research conducted by Katila et al. [27-29].

Based on the results of this study, it can be proposed several models of self-assistance in water resources conservation in the Upstream of Renggung watershed as follows:

1. Development of village owned Fruit and ornamental plants Tourism Park

Economic approach until now is considered to be a quite appropriate method in strengthening the participation of local communities in conservation $[30,31]$. The creation of a Village Owned Fruit and Ornamental Plant Tourism Park in the vicinity of a water source area is one of realistic economic engineering in the upstream area of the Renggung watershed. The tourism park is equipped with facilities such as parking area, restroom, prayer room, playground, and facilities for breeding and / or breeding of endemic fauna as well as a show room for seedlings that are ready to sell. As a tourism park, it will be more interesting if in that area there are gazebo, a fishing pond and culinary tours. To ensure the sustainability of the program in relation to the existence of a tourist park and the contribution of water users to the conservation of water sources, a regulation is required.

2. Empowerment of Productive Economic Enterprises

With regard to increasing community self-assistance in the water resources conservation activities, one alternative solution that can be taken is family economic empowerment. This economic empowerment is attempt to have multiple objectives/goals. It not only to improve the welfare of the assisted/targeted communities, but it is also hoped that it can increase community self-assistance in conserving water resources. One of the potential activities to be developed in the upstream area of the Renggung River Basin is the Development of Small Business of Non-Timber Forest Products (NTFP). Forest Utilization of Non-Timber Forest Products has not been developed optimally as part of sustainable forest resource management. NTFPs that are possible to be developed in forest areas are honey, medicinal plants, sap from palm, edible mushrooms, ornamental plants, animal feed, freshwater fisheries, and other productive business activities. Denada et al. [32] explained that the development of non-timber forest products activities can be integrated with other activities both in forest areas and outside forests such as in yards or community gardens that 
have not been optimally utilized.

Based on experience in the development of various types of agricultural commodities, the main factor that most determines the success and sustainability of community (farmers) businesses is the availability of markets. This experience can be adopted for the development of medicinal plants, which until now has a very limited market with uncertain prices. Therefore, to ensure the sustainability of this business, an alternative that can be done is the development of group development in the form of an Integrated Partnership Program [33-36]. In this case the partnership cooperation involves three parties, that are: (1) the community as plasma participants who are members of a cooperative or joint business group; (2) herbal medicine processing industry or inter-island traders as business partners; and (3) local government as facilitator to coordinate with related agencies/agencies, NGOs, and universities.

3. Development of Compensation for Planting tree in Conservation Area

Compensation for planting trees is meant to develop good timber trees for water resource conservation by the community [37-40]. These trees can be planted on one's own land, in a protected spring area, or in other public places in the upstream area of the Renggung watershed. The trees must be maintained and should not be felled (wood harvested). For this, the community (tree owner) is compensated for the functional benefits of the tree. Contributor for benefit compensation can be individuals (environmentalists), environmental groups/NGOs, companies (CSR), the government, or others. Participants who are involved are prioritized for those who do not have farming land (land tuna). Regarding the amount of compensation value, the minimum time limit (tree age) and the size of the tree that can be compensated, and other rules are determined based on community agreement regulated by the local village government.

\section{CONCLUSION}

Initiatives and the level of community self-assistance in the conservation of water resources in the upstream area of the Renggung watershed are in the "low" category. Family socio-economic characteristics that have a significant effect on the level of self-assistance conservation are age and family income. Age has a positive effect, while income has a negative effect. Self-assistance conservation models in the upstream area of the Renggung watershed that can be developed are: (1) development of village-owned fruit and ornamental plant tourism parks, (2) empowerment of productive economic enterprises, and (3) development of compensation for conservation plants. It is hoped that initiatives and self-assistance in water resources conservation in the upstream area of the Renggung watershed need to be developed in all levels of society. The programs offered should be able to become an economic incentive for the community to increase self-assistance in water resource conservation.

\section{REFERENCES}

[1] Irawan, D.E., Silaen, H., Sumintadireja, P., Lubis, R.F.,
Brahmantyo, B., Puradimaja, D.J. (2014). Groundwatersurface water interaction of Ciliwung River Stream, Bogor-Jakarta Segment, Indonesia. Environmental Earth Science, 73: 1295-1302. https://doi.org/10.1007/s12665-014-3482-4

[2] Muta'ali, L. (2012). Environmental carying capacity based on spatial planning. Indonesian Journal of Geography, $\quad 43(2)$ : https://doi.org/10.22146/ijg.2382

[3] Liu, Y., Chen, Y. (2006). Impact of population growth and land-use change on water resources and ecosystems of the arid Tarim River basin in Western China. International Journal of Sustainable Development and World Ecology, 13(4): 295-305. https://doi.org/10.1080/13504500609469681

[4] Sukardi, L., Bambang, D., Idris, H.M. (2019). Local community participation in protection area of water resources conservation in the Rinjani Forest Management Unit (FMU) of Rinjani Barat, Lombok Island. Sumatra Journal of Disaster, Geography and Geography Education, 3(2): https://doi.org/10.24036/sjdgge.v3i2.244

[5] Sudarmadji, Slamet, S., Setiadi. (2012). Community Based Spring Conservation in Gunung Kidul Regency. SPs-UGM, Yogyakarta.

[6] Marganingrum, D. (2007). Kondisi Citarum Saat ini dan Strategi Pengendaliannya dalam Sumberdaya Air dan Lingkungan Potensi, Degradasi dan Masa Depan. LIPI Press, Jakarta.

[7] Arsyad, S. (2006). Konservasi Tanah dan Air. IPB Press, Bogor.

[8] Hermon, D. (2019). Land stability model for sustainable spatial planning in Padang City-Indonesia based on landslide disaster. Journal of Geography and Earth Sciences, $\quad 7(1)$ : $19-26$. https://doi.org/10.15640/jges.v7n1a2

[9] Setyowati, D.L., Juhadi, Kiptida'iyah, U. (2017). Konservasi Mata Air Senjoyo melalui peran serta masyarakat dalam melestarikan nilai kearifan lokal. Indonesian Journal of Conservation, 6(1): 36-43.

[10] Sihotang, I.V., Sudarmadji, S., Purnama, S., Baiquni, B. (2016). Model konservasi sumberdaya air sebagai upaya mempertahankan keberlanjutan air di Sub DAS Aek Silang. Jurnal Spatial-Wahana Komunikasi dan Informasi Geografi, 5(1): 1-11. https://doi.org/10.21009/spatial.151

[11] Kodotie, R.J., Syarief, R. (2005). Pengelolaan Sumber Daya Air Terpadu. Andi, Yogyakarta.

[12] Sukardi, L., Sa'diyah, H., Husni, S. (2015). Alternatif peningkatan partisipasi ibu rumah tangga masyarakat lokal dalam perlindungan mata air di kawasan hutan Rinjani Lombok Tengah. Agrimansion, 16(1): 32-46. https://doi.org/10.29303/agri.v16i1.11

[13] Kustamar. (2016). Konservasi sumberdaya air di Hulu DAS. Prosiding Temu Ilmiah IPLBI 2016, 1-10.

[14] Ichsan, A.C., Aji, I.M.L., Webliana, K., Sari, D.P. (2019). The analysis of institutional performance of the village conservation model in Gunung Rinjani National Park. IOP Conference Series: Earth and Environmental Science, 270(1): http://dx.doi.org/10.1088/1755-1315/270/1/012019

[15] Ichsan, A.C., Aji, I.M.L., Anwar, H., Waru, T., Febryano, I.G. (2020). The implementation of conservation village model program in Mount Rinjani 
National Park (A Regulation Perspective). Ecology, Environment and Conservation, 26(3): 144-153.

[16] Sukardi, L., Darusman, D., Sundawati, L., Hardjanto, H. (2009). Persepsi dan partisipasi masyarakat lokal dalam pengelolaan Taman Nasional Gunung Rinjani Pulau Lombok. $\quad$ Agrimansion, $10(1)$ : $1-9$. https://doi.org/10.29303/agri.v10i1.213

[17] Maria, R., Lestiana, H., Mulyono, A. (2012). Upaya konservasi tanah dan air dengan agroforestri di Subang Selatan. Prosiding Pemaparan Hasil Penelitian Pusat Penelitian Geoteknologi LIPI-2012, 167-176.

[18] Sudarmadji. (2011). Community-based spring conservation in the physiography unit of Baturagung Mountains, Ledok Wonosari and Gunung Sewu Karst Hills, Gunung Kidul Regency. Journal of Technoscience, 1(1): 42-53 https://doi.org/10.22146/teknosains.3990

[19] Sukardi, L., Darusman, D., Sundawati, L., Hardjanto, H. (2008). Karakteristik dan Faktor Penentu Interaksi Masyarakat Lokal dengan Taman Nasional Gunung Rinjani (TNGR) Pulau Lombok. Agroteksos, 18: 1-3.

[20] Nazir, M. (1983). Metode Penelitian. Ghalia Indonesia, Jakarta.

[21] Febryano, I.G., Harum, O.M.A., Wulandari, C., Hidayat, W., Banuwa, I.S., Prasetia, H., Iswandaru, D., Novriyanti, N., Duadji, N., Tresiana, N., Zulfiani, D., Ichsan, A.C., Salampessy, M.L. (2021). Raw material of Besemah traditional house construction in Indonesia. Folia Forestalia Polonica Series A-Forestry, 63(1): 7480. https://doi.org/10.2478/ffp-2021-0008

[22] Meuller, D.J. (1986). Measuring Social Attitudes: A Handbook for Researchers and Practitioners. Teachers College Press, New York.

[23] Rahadiani, A.A.S.D., Dharma, I.G.B.S., Norken, I.N. (2014). Partisipasi masyarakat sekitar Danau Beratan dalam konservasi sumber daya air. Jurnal Spektran, 2(2): 41-49.

https://doi.org/10.24843/SPEKTRAN.2014.v02.i02.p06

[24] Gebara, M.M. (2018). Tenure reforms in indigenous lands: decentralized forest management or illegalism? Current Opinion in Environmental Sustainability, 32: 60-67. https://doi.org/10.1016/j.cosust.2018.04.008

[25] Salampessy, M.L., Febryano, I.G. (2019). Community behavior study in domestic waste management around the Ciapus River, Babakan Village, Bogor Regency, West Java. IOP Conference Series: Earth and Environmental Science, $407(1)$ : 012004. http://dx.doi.org/10.1088/1755-1315/407/1/012004

[26] Salampessy, M.L., Febryano, I.G., Widhyastini, I.G.A.M. (2021). Community perception on the utilization of natural resources in the Cisadane Watershed. IOP Conference Series: Earth and Environmental Science, $739(1)$ : 012007. http://dx.doi.org/10.1088/1755-1315/739/1/012007

[27] Katila, P., McDermott, C., Larson, A., Aggarwal, S., Giessen, L. (2020). Forest tenure and the Sustainable Development Goals - A critical view. Forest Policy and Economics, 120:

102294. https://doi.org/10.1016/j.forpol.2020.102294

[28] McLain, R., Lawry, S., Guariguata, M.R., Reed, J. (2021). Toward a tenure-responsive approach to forest landscape restoration: A proposed tenure diagnostic for assessing restoration opportunities. Land Use Policy,
104: 103748.

https://doi.org/10.1016/j.landusepol.2018.11.053

[29] Stickler, M.M., Huntington, H., Haflett, A., Petrova, S., Bouvier, I. (2017). Does de facto forest tenure affect forest condition? Community perceptions from Zambia. Forest Policy and Economics, 85: 32-45. https://doi.org/10.1016/j.forpol.2017.08.014

[30] Herwanti, S., Febryano, I.G., Zulfiani, D. (2019). Economic value analysis of community forest food products in Ngarip village, Ulu Belu Subdistrict, Tanggamus Regency (A case from Indonesia). Forestry Ideas, 25(2): 314-328.

[31] Ilfa, A.A., Supratman, S., Sahide, M.A.K. (2021). Partisipasi pemuda dalam pengelolaan hutan kemasyarakatan di Desa Kahayya Kabupaten Bulukumba. Jurnal Belantara, 4(1): 26-38. https://doi.org/10.29303/jbl.v4i1.600

[32] Denada, A.N.I., Winarno, G.D., Iswandaru, D., Fitriana, Y.R. (2020). Analisis persepsi pengunjung mengenai pengelolaan lebah madu untuk mendukung kegiatan ekowisata di Desa Kecapi, Kalianda, Lampung Selatan. Jurnal Belantara, 3(2): 153-162. https://doi.org/10.29303/jbl.v3i2.500

[33] Bowditch, E.A.D, McMorran, R., Bryce, R., Smith, M. (2019). Perception and partnership: Developing forest resilience on private estates. Forest Policy and Economics, 99: 110-122. https://doi.org/10.1016/j.forpol.2017.12.004

[34] Elva, E., Kaskoyo, H., Febryano, I.G., Yuwono, S.B. (2017). Kajian Kelembagaan Gabungan Kelompok Tani dalam Program Kemitraan di KPHP Way Terusan. Jurnal Hutan Tropis, 5(1): 1-8. https://doi.org/10.20527/jht.v5i1

[35] Setiawan, R., Febryano, I.G., Bintoro, A. (2018). Partisipasi masyarakat pada pengembangan agroforestri dalam program kemitraan di KPH Unit XIV Gedong Wani. Jurnal Sylva Lestari, 6(3): 56-63. https://doi.org/10.23960/js13656-63

[36] Wandira, A., Kaskoyo, H., Febryano, I.G., Yuwono, S.B. (2020). Implementasi kemitraan kehutanan di Kesatuan Pengelolaan Hutan Produksi Way Terusan. Jurnal Hutan Tropis, 8(3): 244-250. https://doi.org/10.20527/jht.v8i3.9622

[37] Chang, Y.X., Zhang, Z., Yoshino, K., Zhou, S. (2020). Farmers' tea and nation's trees: A framework for ecocompensation assessment based on a subjectiveobjective combination analysis. Journal of Environmental Management, 269: 110775. https://doi.org/10.1016/j.jenvman.2020.110775

[38] Sukardi, L. (2009). Desain model pemberdayaan masyarakat lokal dalam pengelolaan hutan berkelanjutan. Dissertation. Sekolah Pascasarjana IPB, Bogor.

[39] Tjoa, M., Suharjito, D., Kartodiharjo, H., Soetarto, E. (2018). Hak penguasaan lahan hutan pada masyarakat adat di Desa Honitetu Kabupaten Seram Bagian Barat, Maluku. Jurnal Sylva Lestari, 6(3): 91-102. https://doi.org/10.23960/js13691-102

[40] Yiwen, Z., Kant, S., Dong, J., Liu, J. (2020). How communities restructured forest tenure throughout the top-down devolution reform: Using the case of Fujian, China. Forest Policy and Economics, 119: 102272. https://doi.org/10.1016/j.forpol.2020.102272 